\title{
DISCRIMINATION OF MEMBERS OF THE MYCOBACTERIUM AVIUM COMPLEX BY POLYMERASE CHAIN REACTION
}

\author{
Marcelo Palma Sircili ${ }^{1}$; Eliana Roxo² ${ }^{2}$ Sylvia Cardoso Leão ${ }^{1^{*}}$ \\ ${ }^{1}$ Departamento de Microbiologia, Imunologia e Parasitologia, Universidade Federal de São Paulo, \\ Escola Paulista de Medicina, São Paulo, SP, Brasil. ${ }^{2}$ Seção de Patologia Clínica, Instituto \\ Biológico, São Paulo, SP, Brasil
}

Submitted: September 04, 1998; Returned to authors for corrections: December 02, 1998; Approved: April 08, 1999

\section{SHORT COMMUNICATION}

\begin{abstract}
Mycobacterium avium complex (MAC) species cannot be discriminated by the usual methods of biochemical identification of mycobacteria. This study showed that amplification by PCR of DT1 and DT6, two single copy sequences identified in the genome of $M$. avium serotype 2 , the insertion sequence IS 1245 , found to be consistently present in $M$. avium strains and the heat-shock protein gene $h s p 65$, followed by restriction polymorphism analysis, are rapid and accurate tests for the differentiation of the species M. avium, M. intracellulare, and M. scrofulaceum.
\end{abstract}

Key words: amplification, PCR, MAC, Mycobacterium, identification

Infections caused by Mycobacterium avium complex (MAC) were infrequent in the pre-HIV era, appearing in patients with preexisting lung conditions (6). The importance of these mycobacteria, particularly of M. avium, increased in the last years due to its role as opportunist and cause of disseminated infections in patients with AIDS $(9,18)$. In a study with 125 bone marrow aspirates from AIDS patients in São Paulo, Brazil, conducted between 1990 and 1992, MAC was isolated from 23 samples (18.4\%) and Mycobacterium tuberculosis from 9 (7.2\%). Between 1985 and 1990, only 11 MAC positive cultures were isolated among 60,000 cultures from HIV-negative patients in São Paulo (2). These findings suggest that MAC is an important opportunist in Brazil, specially among AIDS patients.

Further evaluation of the possible reservoirs for MAC infection in humans are needed, and the development of molecular methods for the determination of strain relatedness will certainly improve the epidemiological studies of $M$. aviumrelated infections.

The precise diferentiation of MAC species is a fundamental step in epidemiological studies. MAC consists of a group of 28 serovars including two closely related species, $M$. avium and $M$. intracellulare and this designation may also include other less defined groups. These bacteria have also been referred as M.avium-M.intracellulare complex. The usual methods for identifying Mycobacterium

*Corresponding author. Mailing address: Universidade Federal de São Paulo, Escola Paulista de Medicina, Departamento de Microbiologia, Imunologia e Parasitologia, Rua Botucatu, 862, $3^{\circ}$ andar, CEP 04023-062, São Paulo, SP, Brasil. Fax: (+5511) 5716504. E-mail: scleao.dmip@epm.br 
species based on bacteriological characteristics and biochemical tests may not be accurate for the phenotypic differentiation of the these species and most laboratories report strains as members of MAC. Although the term MAC is reserved for groups of clinical isolates that normally do not include $M$. scrofulaceum, similar plasmids can be found in strains referred to as M. avium, M. intracellulare and M. scrofulaceum. This group is known as MAIS or as $M$. avium- M. intracellulare-M. scrofulaceum complex (4).

Differentiation can be achieved by serotype determination $(7,15)$, but this methodology is applied in few reference laboratories. The commercial AccuProbe Culture Identification Test (Gen-Probe Inc., San Diego, Ca) is a sensitive and specific method and is now used by many clinical laboratories. Nevertheless, besides being an expensive test, it has been reported that many isolates do not react with these probes (5). The $16 \mathrm{~S}$ rRNA sequencing has been particularly helpful in clarifying the complex taxonomical status of the members of the M.avium-M.intracellulare complex. $(12,13)$. Unfortunately, this methodology remains relatively cumbersome, with application limited to reference laboratories.

PCR could be a useful alternative for the identification of MAC species in the clinical laboratory and also for epidemiological and taxonomical studies. Several methods for the differentiation of members of MAC have been reported. DT1 and DT6 are single copy sequences identified in the genome of M. avium serotype 2 (17). Positive amplification of DT6 with primers AV6/AV7 has been obtained with M.avium strains, and DT1 has been amplified with primers IN38/IN41 in $M$. intracellulare strains. The insertion sequence IS 1245 was found to be consistently present in M. avium strains and has been used for analysis of strain relatedness $(3,8,11)$. The procedure called polymorphism restriction analysis (PRA), based on the enzymatic amplification of the hsp65 gene followed by digestion with BstEII and HaeIII was developed by Telenti et al. (16). The authors identified 29 mycobacterial species and subspecies, including members of MAC. In this study we compared these three different PCR techniques in eighteen isolates, identified as MAC by biochemical methods (10) (Table 2).

A loopfull of mycobacteria grown on solid medium (Lowenstein-Jensen, Stonebrink, or
Petragnani) was suspended in $0.4 \mathrm{ml}$ of TE (Tris$\mathrm{HCl} \mathrm{pH} 7.410 \mathrm{mM}$, EDTA $1 \mathrm{mM}$ ) with $1 \%$ Triton X100 and was submitted to three cycles of freezing and thawing. Five to ten microliters of the lysates were used for the PCR reactions.

DT1/DT6 PCR was performed as described by Thierry et al. (17), IS 1245 amplification was described by Guerrero et al. (8), and the PRA reaction was performed as described by Telenti et al. (16) Primers and PCR conditions are described in Table 1. The positive control for the PCR was purified DNA of $M$. avium serotype 2 (ATCC 25291). Positive and negative controls were included in all assays. PCR amplicons and digestion products were electrophoresed through 1\% agarose (Gibco) or 2\% NuSieve (FMC Bioproducts) $/ 2 \%$ agarose gels, respectively. The gels were stained with ethidium bromide (Sigma) and photographed on a UV transilluminator. PCR results were compared and a genetic identification was obtained.

Positive amplification with the DT6 primers was obtained from 13 out of 18 strains: ten human and animal isolates identified as MAC, two reference M. avium strains (number 3 and 12) and the strain serotype VIII (number 16) identified previously as $M$. intracellulare. With the DT1 primers, amplification was positive in 4 out of 18 strains: one animal isolate biochemically identified as MAC (number 11), two isolates representing the same reference $M$. intracellulare strain, before and after passage through animal (mouse) (number 13 and 14) and one reference $M$. avium/intracellulare strain (number 18) (Fig. 1). One strain biochemically identified as $M$. intracellulare (number 15) and $M$. scrofulaceum (number 17) did not amplify with either pair of primers. Therefore, the genetic identification of these two strains could not be obtained solely by this approach. Amplification with both pairs of primers was obtained from a MAC isolate from a zoo bird (number 11) and from the positive control, ATCC 25291. According to the group that sequenced the DT1 and DT6 fragments, strains amplifying with both pairs of primers could represent $M$. avium serotype 2 or 3 (17). Comparing the results of DT1 and DT6 amplifications, species identification could be obtained in 16 out of 18 strains (Table 2).

Amplification with the IS 1245 primers was positive in all clinical isolates identified biochemically as MAC and the reference M.avium strains (D4, 20485 and ATCC25291) (Fig. 1). DNA from strain serotype VIII, previously identified as 
Table 1 - Primers and PCR conditions used in this work.

\begin{tabular}{|c|c|c|}
\hline PRIMERS & PCR MIX & PCR \\
\hline $\begin{array}{l}\text { DT6 } \\
\text { AV6:5'-ATGGCCGGGAGACGATCTATGCCGGCGTAC-3', } \\
\text { AV7:5'-CGTTCGATCGCAGTTTGTGCAGCGCGTACA-3' } \\
\text { DT1 } \\
\text { IN38:5'-GAACGCCCGTTGGCTGGCCATTCACGAAGGAG-3' } \\
\text { IN41:5'-GCGCAACACGGTCGGACAGGCCTTCCTCGA-3' }\end{array}$ & $\begin{array}{l}\text { 1X Buffer (Gibco), } 2 \mathrm{mM} \\
\mathrm{MgCl}_{2}, 200 \mu \mathrm{M} \text { DNTPs, } 100 \mu \mathrm{g} / \\
\text { ml BSA, 100pmols of each } \\
\text { primer, 2U Taq polymerase }\end{array}$ & $\begin{array}{l}\text { Denaturation } 94^{\circ} \mathrm{C} 5 \mathrm{~min} ., 25 \\
\text { cycles at } 94^{\circ} \mathrm{C} 1 \mathrm{~min} ., 60^{\circ} \mathrm{C} 1 \\
\text { min., } 72^{\circ} \mathrm{C} 1 \mathrm{~min} . \\
\text { Final extension } 72^{\circ} \mathrm{C} 7 \mathrm{~min} .\end{array}$ \\
\hline $\begin{array}{l}\text { IS1245 } \\
\text { P1: 5'-GCCGCCGAAACGATCTAC-3' } \\
\text { P2: 5'-AGGTGGCGTCGAGGAAGC-3' }\end{array}$ & $\begin{array}{l}\text { 1X Buffer (Gibco), } 1,5 \mathrm{mM} \\
\mathrm{MgCl}_{2}, 200 \mu \mathrm{M} \text { DNTPs, } 10 \% \\
\text { glycerol, } 0,5 \mu \mathrm{M} \text { of each } \\
\text { primer, } 1 \mathrm{U} \text { Taq polymerase }\end{array}$ & $\begin{array}{l}\text { Denaturation } 94^{\circ} \mathrm{C} 5 \mathrm{~min} ., 30 \\
\text { cycles at } 94^{\circ} \mathrm{C} 1 \mathrm{~min} ., 60^{\circ} \mathrm{C} 1 \\
\text { min., } 72^{\circ} \mathrm{C} 1 \mathrm{~min} . \\
\text { Final extension } 72^{\circ} \mathrm{C} 7 \mathrm{~min} .\end{array}$ \\
\hline $\begin{array}{l}\text { PRA } \\
\text { Tb11: 5'-ACCAACGATGGTGTGTCCAT-3' } \\
\text { Tb12: 5'-CTTGTCGAACCGCATACCCT-3' }\end{array}$ & $\begin{array}{l}1 \mathrm{X} \text { Buffer (Gibco), } 1,5 \mathrm{mM} \\
\mathrm{MgCl}_{2}, 200 \mu \mathrm{M} \text { DNTPs, } 10 \% \\
\text { glycerol, } 0,5 \mu \mathrm{M} \text { of each } \\
\text { primer, } 1 \mathrm{U} \text { Taq polymerase }\end{array}$ & $\begin{array}{l}\text { Denaturation } 94^{\circ} \mathrm{C} 5 \mathrm{~min} ., 45 \\
\text { cycles at } 94^{\circ} \mathrm{C} 1 \mathrm{~min} ., 65^{\circ} \mathrm{C} 1 \\
\text { min., } 72^{\circ} \mathrm{C} 1 \mathrm{~min} . \\
\text { Final extension } 72^{\circ} \mathrm{C} 7 \mathrm{~min} .\end{array}$ \\
\hline
\end{tabular}

Table 2 - Isolates and strains, PCR results and biochemical identification. + and - indicate positive and negative amplification by PCR, respectively. PRA identification was obtained after BstEII and HaeIII digestion of the hsp65 amplicons.

\begin{tabular}{ccccccc}
\hline Number & Strain/Isolate & $\begin{array}{c}\text { Biochemical } \\
\text { Identification }\end{array}$ & DT1 & DT6 & IS1245 & PRA \\
\hline 1 & Human & MAC & - & + & + & M. avium \\
2 & Human & MAC & - & + & + & M. avium \\
3 & D4* & MAC & - & + & + & M. avium \\
4 & Bovine lymph node & MAC & - & + & + & M. avium \\
5 & Swine lymph node & MAC & - & + & + & M. avium \\
6 & Bovine lung & MAC & - & + & + & M. avium \\
7 & Bovine lung & MAC & - & + & + & M. avium \\
8 & zoo bird cecum & MAC & - & + & + & M. avium \\
9 & zoo bird feces & MAC & - & + & + & M. avium \\
10 & Swine lymph node & MAC & - & + & + & M. avium \\
11 & Crane intestine & MAC & + & + & + & M. avium \\
12 & 20485 & M. avium & - & + & + & M. avium \\
13 & CC1400/mouse & M. intracellulare & + & - & - & M. intracellulare \\
14 & CC1400/mouse & M. intracellulare & + & - & - & M. intracellulare \\
15 & IB collection** & M. intracellulare & - & - & - & M. intracellulare \\
16 & Serotype VIII & M. intracellulare & - & + & + & M. avium \\
17 & IB collection** & M. scrofulaceum & - & - & - & M. scrofulaceum \\
18 & ATCC13950 & M. avium-intracellulare & + & - & - & M. intracellulare \\
+ & ATCC25291 & M. avium & + & + & + & M. avium \\
\hline
\end{tabular}

* D4 = avian PPD strain

** IB = Instituto Biológico, São Paulo 


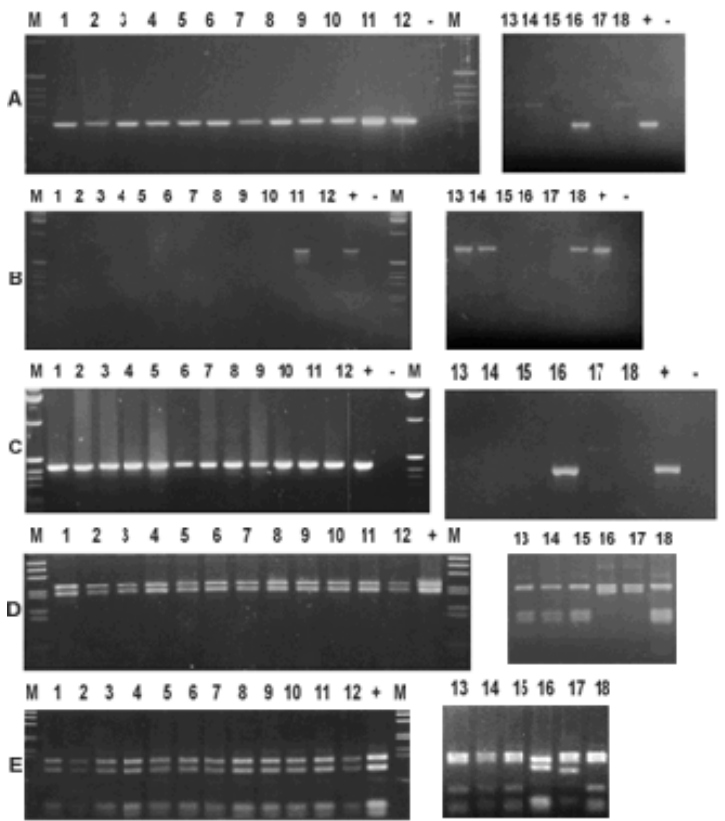

Figure 1: Agarose gel stained with ethidium bromide showing results of amplification of fragments DT6 (A), DT1 (B), IS 1245 (C) and hsp65 digested with BstEII (D) and HaeIII (E). 1 - 18: isolates described in Table 2, M: 1kb DNA ladder (Gibco/BRL), + positive control, M. avium ATCC 25291, - negative control

M. intracellulare (number 16), amplified with these primers. It also amplified with the DT6 primers, as has been shown above. Serotype VIII was identified as $M$. intracellulare before the DNA-DNA hybridization studies were performed $(7,15)$. After that it has been identified as M. avium $(1,14)$. The results obtained in this study agree with this last identification.

All strains were amplified by the $h s p 65$ gene primers. The bands obtained after BstEII and HaeIII enzymatic digestions were analysed using the Molecular Analyst Software (BioRad). The patterns were specific for $M$. avium, M. intracellulare and M. scrofulaceum and species discrimination could be easily performed by visual inspection (Fig. 1).

The combined analysis of the three PCR protocols and comparison to the biochemical identification showed that PCR is a useful method for the identification of species belonging to MAC. Better results were obtained by combining different amplification methods or by the PRA method. PCR is simple, rapid and easily performed in multiple samples. It can be a useful tool in epidemiological medical and veterinarian studies. This identification approach could not only give important insights for the control of infections caused by these bacteria, but also would help to clarify the complex taxonomical status of their members.

\section{RESUMO}

\section{Identificação molecular de membros do complexo Mycobacterium avium}

A identificação bioquímica de micobactérias não permite a discriminação das espécies do complexo Mycobacterium avium (MAC). Este estudo mostrou que a amplificação por PCR de DT1 e DT6, duas sequências de cópia única identificadas no genoma de $M$. avium sorotipo 2, da sequência de inserção IS1245, encontrada consistentemente em cepas de M. avium e de um fragmento do gene da proteína de choque térmico hsp65, seguida da análise do polimorfismo de restrição, são testes rápidos $\mathrm{e}$ acurados para a diferenciação das espécies M. avium, M. intracellulare e M. scrofulaceum.

Palavras-chave: amplificação, PCR, MAC, Mycobacterium, identificação

\section{REFERENCES}

1. Baess, I. Deoxyribonucleic acid relationships between different serovars of Mycobacterium avium, Mycobacterium intracellulare and Mycobacterium scrofulaceum. Acta Pathol.Microbiol.Scand.Sect.B,91:201-203,1983.

2. Barreto, J. A.; Palaci, M.; Ferrazoli, L.; Martins, M. C.; Suleiman, J.; Lorenço, R.; Ferreira Jr., O. C.; Riley, L. W.; Johnson Jr., W. D.; Galvão, P. A. Isolation of Mycobacterium avium complex from bone marrow aspirates of AIDS patients in Brazil. J.Infect.Dis., 168:777-779,1993.

3. Bono, M.; Jemmi, T.; Bernasconi, C.; Burki, D.; Telenti, A.; Bodmer, T. Genotypic characterization of Mycobacterium avium strains recovered from animals and their comparison to human strains. Appl.Environ.Microbiol., 61:371-373,1995.

4. Crawford, J.T.; Falkinham III, O. Plasmids of the Mycobacterium avium complex. In: McFadden, J. (ed.) Molecular Biology of Mycobacteria. Surrey University Press, London,1990, p.97-120.

5. Devalois, A.; Picardeau, M.; Paramasivan, C. N.; Vincent, V.; Rastogi, N. Molecular characterization of Mycobacterium avium complex isolates giving discordant results in AccuProbe tests by PCR-restriction enzyme analysis, 16S rRNA gene sequencing, and DT1-DT6 PCR. J.Clin.Microbiol.,35:2767-2772,1997.

6. Falkinham III, J. O. Epidemiology of Mycobacterium avium infections in the pre- and post-HIV era. Res. Microbiol.,145:169-172,1994.

7. Good, R.C.; Beam, R.C. Seroagglutination. In: Kubica G.P. and L.G. Wayne (ed.) The mycobacteria: a sourcebook. Part A. Marcel Dekker, Inc.,New York, 1984, p.105-122. 
8. Guerrero, C.; Bernasconi, C.; Burki, D.; Bodmer, T.; Telenti, A. A novel insertion element from Mycobacterium avium, IS 1245 , is a specific target for analysis of strain relatedness. J.Clin.Microbiol, 33:304-307,1995.

9. Inderlied, C.B.; Kemper, C. A.; Bermudez, L. E. M. The Mycobacterium avium complex. Clin.Microbiol.Rev., 6:266$310,1993$.

10. Kantor, I. N. Bacteriologia de la tuberculosis humana y animal. OPS/OMS. Serie de Monografias Cientificas y Tecnicas $\mathrm{N}^{\circ} 11 / \mathrm{Rev}$. I, 1988, p. 63.

11. Ritacco, V.; Kremer, K.; van der Laan, T.; Pijnenburg, J. E. M.; de Haas, P. E. W.; van Soolingen, D. Use of IS901 and IS1245 in RFLP typing of Mycobacterium avium complex: relatedness among serovar reference strains, human and animal isolates. Int.J.Tub.Lung.Dis., 2:242-251,1998.

12. Rogall, T.; Flohr, T.; Böttger, E. Differentiation of Mycobacterium species by direct sequencing of amplified DNA. J. Gen. Microbiol., 136:1915-1920,1990.

13. Rogall, T.; Wolters, J.; Flohr, T.; Böttger, E. Towards a phylogeny and definition of species at the molecular level within the genus. J Mycobacterium. Int.J.Syst.Bacteriol., 40:323-330,1990.
14. Saito, H.; Tomioka, H.; Sato, K.; Tasaka, H.; Dawson, D. J. Identification of various serovar strains of Mycobacterium avium complex by using DNA probes specific for Mycobacterium avium and Mycobacterium intracellulare. J.Clin.Microbiol., 28:1694-1697,1990.

15. Schaefer, W. B. Serologic identification and classification of the atypical mycobacteria by their agglutination. Am.Rev.Respir.Dis.,92 (Suppl.):85-93, 1965.

16. Telenti, A.; Marchesi, F.; Balz, M.; Bally, F.; Böttger, E. C., Bodmer, T. Rapid identification of mycobacteria to the species level by polymerase chain reaction and restriction analysis. J.Clin.Microbiol., 31:175-178,1993.

17. Thierry, D.; Vincent, V.; Clement, F.; Guesdon, J. L.. Isolation of specific DNA fragments of Mycobacterium avium and their possible use in diagnosis. J.Clin.Microbiol., 31:1048$1054,1993$.

18. Yakrus, M. A.; Good, R. C. Geographic distribution, frequency, and specimen source of Mycobacterium avium complex serotypes isolated from patients with acquired immunodeficiency syndrome. J.Clin.Microbiol, 157:863867,1990 . 